\title{
EQUiLIBRIUM
}

Quarterly Journal of Economics and Economic Policy

2015 VOLUME 10 ISSUE 1, March

p-ISSN 1689-765X, e-ISSN 2353-3293

www.economic-policy.pl

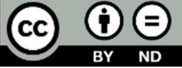

Dominiak, P., Lechman, E., \& Okonowicz, A. (2015). Fertility Rebound and Economic Growth. New Evidence for 18 Countries Over the Period 1970-2011. Equilibrium. Quarterly Journal of Economics and Economic Policy, 10(1), pp. 91-112, DOI: http://dx.doi.org/10.1 2775/EQUIL.2015.005

Piotr Dominiak, Ewa Lechman Anna Okonowicz ${ }^{*}$

Gdansk University of Technology, Poland

\section{Fertility Rebound and Economic Growth. New Evidence for 18 Countries Over the Period 1970-2011}

JEL Classification: $J 11 ; O 10 ; C 23$

Keywords: fertility rate; fertility rebound; economic growth; panel data analysis

\begin{abstract}
Long-run impact of economic growth on fertility trends is ambiguous and sensitive for in-time variations. Noticeably, over last decades, economic growth has led to significant falls in total fertility rates in many countries. However, recently, in high-income economies a kind of 'fertility rebound' emerged (Goldstein, 2009; Luci and Thevenon, 2011; Day, 2012), which supports the hypothesis that reversal trends in total fertility rates are mainly attributed to economic growth. The paper unveils the relationship between total fertility rate changes and economic growth in 18 selected countries with fertility rebound observed, over the period 1970-2011, and detects the GDP-threshold at which the fertility rebound emerged. To report on the relationship we deploy longitudinal data analysis assuming non-linearity between examined variables. The data applied are exclusively derived from World Development Indicators 2013. Our main findings support the hypothesis on $U$-shaped relationship between the total fertility rate and economic growth in analyzed countries in 1970-2011. Along with the previous, we project the minimum level of GDP per capita (GDP-threshold) when the fertility rebound takes place.
\end{abstract}

(C) Copyright Institute of Economic Research \& Polish Economic Society Branch in Toruń Date of submission: December 13, 2014; date of acceptance: February 5, 2015

* Contact: ewa.lechman@zie.pg.gda.pl, piotr.dominiak@zie.pg.gda.pl, anna.okonowicz @ zie.pg.gda.pl, Faculty of Management and Economics, Gdansk University of Technology, ul. Gabriela Narutowicza 11/12, 80-233 Gdańsk, Poland 


\section{Introduction}

In 1994, Hirschman (1994) concluded that the picture arising from empirical evidence on long-term changes in fertility (measured, by convention, as period total fertility rate - TFR) is ambiguous and does not provide clear justification about its direct determinants. After twenty years of further studies, our knowledge about the factors influencing fertility is much broader, however we still lack a hegemonic theory on that field which would allow for answering by which determinants the changes in women's fertility are impacted. Contemporary societies are highly heterogeneous, and the relationship between changing fertility rates and economic development is affected by multitude of quantifiable and unquantifiable factors; still, the negative relationship between fertility and socio-economic development is recognized as one of the best-established and consolidated regularities in social sciences. The cited regularity was empirically confirmed in prominent works of, inter alia, Becker (1960), Heer (1966), Easterline (1975), Van de Kaa (1987), Witte and Wagner (1995), Becker, et al. (1999), Lee (2003), Myrskylä, et al. (2009), Luci and Thévenon (2011) or Bacci (2013). The economic reasoning behind the negative relationship between fertility and economic development is the following. As mortality and fertility rates decline ${ }^{1}$, it allows for reductions in the amounts of energy and resources necessary for childbearing (Kalemli-Ozcan, et al., 2000; Orsal \& Goldstein, 2011; Livi-Bacci, 2012; 2013), resulting in higher women`s engagement in market activities instead, which in turn potentially generates shifts in factor productivity. Weil (2013) also claims that as countries get richer, two specific effects emerge, namely the 'income effect' and the 'substitution effect', which allow for explaining why people tend to have fewer children as their income grows. People value children as 'normal goods' which they need to spend money on. As people earn more, they - theoretically - can afford more children, but the previous is usually not true, as the relative price of rising children also increases. Childbearing requires time, which expresses the opportunity cost of not earning money from regular work; hence, the 'substitution effect' emerges, and if the 'substitution effect' is stronger than the 'income effect' then the country`s fertility falls. Weil (2013) additionally explains that lowering fertility may be determined by emerging 'quality-quantity trade-off' effect. In high-income countries, children need to get good education, which is costly. Thus, people decide to have fewer, but better educated children, hoping for payoffs in the future and children`s support as the parents get older. Alternatively,

\footnotetext{
${ }^{1}$ Note that in demographic perspective, the lowering fertility rates are a consequence of both declined in morality and increases of life expectancy.
} 
they decide to have more children, but at the cost of their worse education. Whether people decide on one or another, depends predominantly on how they value children, what the well-established social norms and attitudes, or individual preferences are. But, as it is claimed by some scholars, see for instances the works by Galor and Weil (1996, 1999), Kohler, et al. (2002a, 2002b), Deopke (2004), Caldwell and Schindlmayr (2003), Butler (2004), Morgan and Taylor (2006), Klasen and Lamanna (2009), Mills, et al. (2011), the total fertility rate and economic development are rather linked by a two-way, than a one-way, relationship. The reverse causality between TFR and economic development is possible, but also heavily preconditioned by a broad array of economic and non-economic factors. However, most recent estimates provide a solid background to claim a reversal of the previous negative associations between TFR and economic growth and development (i.e. Gubhaju \& Moriki-Durand, 2003; Bongaarts \& Sobotka, 2012). To support the previous, it is worth emphasizing that in Europe, the period 1998-2008 was marked by significant changes on the ground of total fertility rates (Bongaarts \& Sobotka, 2012; Sobotka, 2012). In many European countries, TFR began to grow, after having fallen to unprecedentedly low levels in the early 2000s (in 19 European countries, the TFR fell below 2.0). The evidence on a trial of escaping the 'low fertility trap" ${ }^{2}$ in European countries, is reported in the works by, inter alia, Prioux (2007), Goldstein, et al. (2009) or Bongaarts and Sobotka (2012). Over the period 20002011, similar reverse trends in total fertility rate are observable in more than 60 high-developed and economically backward countries (to compare see: World Development Indicators 2013). Surprisingly, Myrskylä, et al. (2009), Day (2012, 2013) and Varvarigos (2013) find that the wellestablished negative relationship between the fertility rate and the economic growth turns to be rather positive, especially, at higher stages of economic

\footnotetext{
${ }^{2}$ The concept of 'low fertility' is to a point ambiguous. As Bacci (2013) argues, in its simplest form, the low fertility occurs when it falls below 1 . In such sense, the fertility rate is totally conditioned by level of mortality ('one for one'). However, in modern societies, where the life expectancy is high and mortality in reproductive years is close to zero, the replacement of populations is strictly depended on total fertility. Societies where the total fertility rates oscillate around two children per women in her reproductive life cycle are labeled as low fertility societies (Bacci, 2012; 2013). If the total fertility declines until around 1 or fewer children per a woman thus is named as 'ultra-low fertility' or 'lowest-low fertility'. The low fertility can be also subjectively perceived. To a point, fertility rates rely on individual expectations or preferences, social norms or ideals, religious attitudes, or finally state strategic targets. In such case, rigid notion of low fertility remains fuzzy and undefined. In general, from purely demographic perspective the concept of low fertility relates exclusively to population replacement, while incorporating the low fertility notion into social or economic ground, allows its perception in context of meeting broadly agreed social, economic or political targets (like i.e. in China 'one child' policy).
} 
development. Hence, the emergence of new regularities between TFR and the economic growth is witnessed. The hypothesis on a potential positive relationship between fertility trends and economic development - labelled as 'U-shaped fertility dynamics' (Day, 2013; Luci-Greulich \& Thévenon, 2013), is supported by evidence on growing total fertility rates mainly in high-income economies (Myrskylä, et al., 2011; Myrskylä, et al., 2013).

The changing trends in fertility rates are labelled fertility rebound, defined as reversal of fertility decline accompanied by economic development.

The aim of the paper is to provide new evidence on the relationship between fertility and economic development, and to estimate the GDPthreshold at which the fertility rebound emerged across countries. To meet the main targets of the paper, we re-examine the hypothesis on a U-shaped relationship, for 18 high-income countries over the period 1970-2011, between total fertility rate (TFR) and GDP per capita. Our study consists of six parts, whereby the introductory part is followed by section two explaining theoretical background and literature review. Section 3 presents data rationale, whereas section four sets the main goals of the paper and adopted empirical strategy. The subsequent section five illustrates empirical analysis results and the final part refers to substantial conclusions in this respect.

\section{Conceptual Background}

Recent empirical studies (see, for instance, works by Goldstein, et al., 2009; Bongaarst \& Sobotka, 2012; Luci-Greulich \& Thevenon, 2013; Day, 2013) provide well-documented evidence on the relationship between TFR and GDP per capita or - alternatively - socio-economic development approximated by Human Development Index. Although the evidence is relatively broad, the main conclusions they allow for vary significantly, showing the complexity of the problem and the multitude of factors which potentially affect the two-way relationship between fertility and economic growth and development. Both in theoretical and empirical works where main emphasis is put on aspects combining fertility trends and economic development $^{3}$, three seminal research streams are easily distinguishable,

\footnotetext{
${ }^{3}$ Along with growing literature on the relationships between total fertility rates and economic development, there is broad empirical evidence providing demographic explanations to reversal fertility trends. Such evidence can be traced in works of, inter alia, Bongaarts and Sobotka (2012), Bongarts and Feeney (1998), Bongaarts (2002), Sobotka (2004), Goldstein, et al. (2009), Frejka (2010), Sobotka, et al. (2011), or Neels and de Wachter (2010a, 2010b).
} 
since each of them offers different perspectives for an analysis. The first stream combines issues of changing fertility with economic development, the second - changing fertility trends with economic growth exclusively, while the third one confronts changing fertility trends with business cycles. The first and the second perspective are mostly long-term in nature, while the third one combined short-, and long-run approach. Myrskylä et al. (2009), in their prominent work, apply panel data for 37 high developed countries over the period 1975 to 2005, to examine the relation between the Human Development Index (HDI) and the total fertility rates. They suggest that HDI-TFR relationship tends to reverse from negative to positive, as countries pass critical level of HDI. Their findings show that, at low and medium level of human development index (HDI), decreases in fertility rate coincide with continuously progressing economic growth. The situation changes diametrically at higher HDI levels. Further development, upon reaching a particular threshold, may lead to a reversal in fertility declining trend. The level of HDI, which turns the correlation between human development and fertility from negative to positive, is at about 0.9 . Following the above, they predict that, in a long-run perspective, advanced in human development shall impact fertility rates positively; however, changes in fertility are not exclusively attributed to economic effect solely. Changing relationship - from negative to positive - between two covariates like total fertility rates and economic development, can be graphically approximated by a U-shaped pattern. Luci and Thévenon (2010) also report on U-shaped relationship between TFR and GDP per capita. Unlike Myrskylä et al. (2009) do, they analyse the impact of GDP per capita on fertility rates, to isolate the pure economic impact on total fertility rates. To test the hypothesis of a convex impact of GDP per capita on TFR, Luci and Thévenon (2010) use a panel data set of 30 OECD countries over the time span 19602007. Applying one step-estimator, they designate the turning point in the relationship between economic growth and fertility, at which further growth may lead to a reversal of fertility decline trend. The minimum of the curve is located at specific GDP per capita that corresponds to approximately 32,600 (in constant 2005 US\$) and total fertility rate at 1.51 children per woman. Separately, they identify country-specific factors, which intend to explain why countries at a comparable level of GDP per capita levels experience different fertility rates. A general conclusion of the study is that economic development is likely to induce the fertility rebound; however, the evidence is not robust and case-sensitive. The evidence provided by Myrskylä et al. (2009) clearly claims that advances in development path, in some cases are accompanies by reverses of declining fertility rate but, by contrast, such conclusion is questioned by Furuoka (2009). Furuoka applies 
a threshold regression to examine the existence of the U-shaped fertilitydevelopment curve proposed by Myrskylä, et al. (2009). He uses threshold HDI (indicated as 0.777) to divide the sample into two subsamples - countries with HDI level equal to or lower than the threshold value and those that exceed the threshold. Thus, the negative relationship between HDI and fertility rate was revealed both in the countries with HDI below and above the threshold, although in the countries with high HDI, the negative relationship between covariates was relatively weak. It supports the supposition that the countries placed in earlier phases on economic development are more likely to experience declining fertility rates, likewise, in highlydeveloped countries it is just the opposite. The aforementioned evidence provided by Myrskylä, et al. (2009) is additionally supported by Goldstein, et al. (2010). They verify the importance of economic conditions for fertility trends, using data on unemployment rates and GDP growth in 27 OECD countries (regardless total fertility rates levels), over the period 1995 to 2008. However, they do not claim direct influence of unemployment on fertility, rather emphasising importance of current economic conditions on individual decisions on childbearing. Goldstein, et al. (2009) find both unemployment and economic growth rates to be statistically significant predictors of prospected TFR. Another stream, both in theoretical and empirical research highlights the importance of distinguishing between short and long-run perspectives when analyzing TFR and GDP per capita relationship. Long-term analysis mainly focuses on macro-factors (on aggregate level) that determine observed changes in fertility, and such approach was presented in aforementioned studies. While short-term analysis - concentrate on examining the impact of business cycles (especially recession) on the period TFR, and refer to individual decisions that may influence changes in TFR (Sobotka, et al., 2011). The majority of short-term analysis shows pro-cyclical relationship between fertility and GDP per capita. During recessions (approximated by GDP per capita declines, growth of unemployment rates etc.) fertility tends to decrease. Such evidence in presented, inter alia, in the works by Lee (1990), Bengtsson, et al. (2004), Martin (2004) or Adsera and Menendez (2009). Sobotka, et al. (2011) confirmed the pro-cyclical relationship between GDP per capita and fertility. They used changes in GDP per capita as a proxy explaining recession and the period TFR as an indicator of fertility (they imposed 1-year lag in GDP per capita impact on TFR changes). Their study (Sobotka, et al., 2011) covered 26 low fertility developed countries over the period 1980-2008, and the results obtained seem to support the hypothesis that fertility and economic growth are positively correlated along business cycles, which was already concluded from previous works (see i.e. Lee, 1990; Bengtsson, et al., 
2004). However, detecting rigid regularities in the behavior of TFR versus GDP per capita if business cycles are considered, huge uncertainties emerge which makes the relationship even fuzzier. The previous was clearly stated in the works by i.e. Kohler, et al. (2002a, 2002b), Santow and Bracher (2001), Mills and Blossfeld (2005), Kreynfeld (2010), Neels (2010) or Sobotka (2010). Circumstance that today`s recessions (i.e. that which started in 2008) take place under, differ significantly from those in the past. This is mainly due to huge increases in women`s active participation in labor market, which is partly determined by their growing access to education, contraceptives, and changing social norms. In effect, the previous may precondition the strength of influence of short-term recessions on changing fertility trends. The counter-cyclical relationship was only mentioned in few studies - i.e. Butz and Ward (1979a, 1979b) or Macukovich (1996). Recent decades are featured by relatively short recessions, thus their real impact on fertility was temporary. The fall of fertility during recessions was followed by its rise (or slower decline) during recoveries. When analyzing trends in fertility in short time perspective, there might arise some difficulties with clear distinguishing between fertility changes and fertility timing (postponement of the birth). Only in few studies, do we observe attempts to tackle the problem just mentioned. Formal analysis trying to combine short and long run perspective in detecting the relationships between economic development and fertility, are found i.e. in the works by i.e. Ogawa (2003) or Rindfuss, et al. (1988). Empirical evidence linking fertility changes with GDP per capita is even scarcer than the previous. Our empirical analysis, presented in following sections of the paper, predominantly concentrates on detecting long-term relationships between changing total fertility rates and GDP per capita.

\section{Data}

Intentionally, our analysis is limited to two variables. Firstly, we account for Total Fertility Rate $\left(\mathrm{TFR}_{\mathrm{it}}\right)$ which refers to the number of children that a woman would give birth to, in accordance with current age-specific fertility rates (see WDI 2013). Secondly, to approximate the level of economic development of countries, we consider gross domestic product per capita $\left(\mathrm{GDPpc}_{\mathrm{it}}\right)$ We take natural logarithms of national GDP per capita in constant 2005 US\$. All data are exclusively derived from World Development Indicators database 2013. To complete our empirical analysis, we construct strongly balanced cross-country long panel including 18 high-income economies that satisfy two prerequisites: over the period 1970-2011 Total 
Fertility Rate has dropped below 2.1 (replacement rate), which was followed by 'fertility rebound', and - according to World Bank - are classified $^{4}$ as high-income countries. Finally, the empirical sample covers Australia, Belgium, Barbados, Canada, Switzerland, Germany, Denmark, Spain, Finland, France, United Kingdom, Greece, Japan, Italy, Netherlands, Norway, Sweden and the United States.

\section{Methodological Settings and Empirical Targets}

The aim of the paper is twofold. Preliminary, using panel data of 18 countries over the period 1970-2011 we aim to confirm - or reject - the hypothesis on U-shaped relationship between Total Fertility Rate and economic growth approximated by GDP per capita. If the latter is positively verified, hence it would be right to claim that the negative relationships between economic growth and total fertility rates turns to be positive, once the specific upswing in TFR long-term trends are reported. Following the above, we estimate the threshold level of GDP-threshold when the fertility rebound effect is revealed. We presume that, in this case, the use of crosssectional analysis yields high appropriateness as the countries included in the sample are heterogeneous. Hence, to test the hypothesized relationship, we perform a panel regressions analysis, as the latter allows for controlling the variables which may not be directly observed and quantified, however if some cases - seem to have a crucial role in determining the nature of the analyzed relationships. This country-individual heterogeneity, which varies across countries, but not across periods, is well captured by the longitudinal models. We claim the fixed effects regressions would be correct to examine the relationships between economic growth and the total fertility rates, as they allow for controlling the relationships emerging between the predictor and the outcomes variable, however presuming that the latter may be affected by some country-specific features, basically time-invariant, not included in the model.

Firstly, we confirm the U-shaped relationship between variables: Total Fertility Rate $\left(\mathrm{TFR}_{\mathrm{it}}\right)$ - response variable; and economic growth (lnGDPp$\mathrm{c}_{\mathrm{it}}$ ) - explanatory variable. For this, adopting pooled OLS, we examine linear model versus 2-degree polynomial (quadratic equation) and 3-degree polynomial (cubic equation). To formalize the above, we specify the general equation:

\footnotetext{
${ }^{4}$ According to formal World Bank country classification (see: http://data.worldbank.org/a bout/country-classifications, accessed: Feb 2014)
} 


$$
\begin{aligned}
& T F R_{i t}=\beta_{0}+\beta_{1} \operatorname{lnGDPp} c_{i t}+\varepsilon_{i t},
\end{aligned}
$$

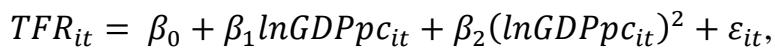

$$
\begin{aligned}
& T F R_{i t}=\beta_{0}+\beta_{1} \operatorname{lnGDPp} c_{i t}+\beta_{2}\left(\operatorname{lnGDPp} c_{i t}\right)^{2}+\beta_{3}\left(\ln G D P p c_{i t}\right)^{3}+\varepsilon_{i t},
\end{aligned}
$$

where $i$ denotes country, $t-$ period (year) and $\varepsilon_{i t^{-}}$an error term. If Ushaped relationship between $\mathrm{TFR}_{\text {it }}$ and $\mathrm{LnGDPpc}_{\text {it }}$ is confirmed, afterwards we exclusively concentrate on quadratic longitudinal models. Using yearly observations, we test convex shape of the curve explaining cross-country relationship between $\mathrm{TFR}_{\mathrm{i}}$ and $\mathrm{LnGDPpc}_{\mathrm{it}}$ and its square term. To capture time-invariant countries`specific effects, we propose, as justified above, country-fixed effects regression, defined as:

$$
T F R_{i t}=\alpha_{i}+\delta_{1} \operatorname{lnGDPp} c_{i t}+\delta_{2}\left(\operatorname{lnGDPp} c_{i t}\right)^{2}+\varepsilon_{i t},
$$

which can be rewritten (if country-dummies included):

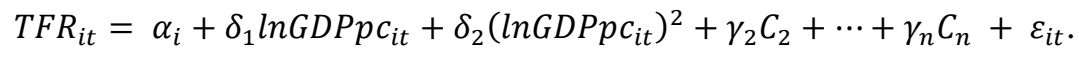

In Eq.(4)-(5), $\alpha_{i}$ denotes unobserved, time-invariant fixed effect, $\gamma_{2}$ is coefficient for binary-country regressors, $C$ - is country-dummy, $n$ accounts for number of countries in the sample, and $\alpha_{i}$ and $\left(\operatorname{lnGDPp} c_{i t}\right)$ are arbitrary correlated. For Eqs.(4)-(5), to satisfy the exogeneity assumption, we assume that $E\left(\varepsilon_{i t} / X_{i}, \alpha_{i}\right)=0$, if $X_{i}$ represents $\left(\ln G D P p c_{i t}\right)$. In the specified model, the $T F R_{i}$ concisely expresses the vector of country`s individual results determined by changes in per capita income, across all periods. To examine time-fixed effects we additionally estimate:

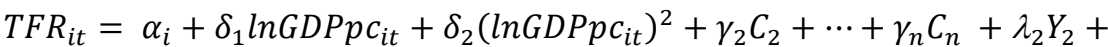

$$
\begin{aligned}
& \ldots+\lambda_{n} Y_{n}+\varepsilon_{i t},
\end{aligned}
$$

where $Y$ is year-dummy and $\lambda$ stands for its coefficient. Hence regression Eq.(6) is estimated for $n-1$ countries and $y-1$ years. In Eq.(6) we relax the assumption on unobserved effects which vary across countries, but are constant over time. Thus, we control for time effects supposing that unexpected variation potentially influence the explanatory variable.

To confirm results generated from Eqs.(5)-(6), along with within estimator we introduce instrumental variables (IV) estimator, which by cutting potential correlation between error term and explanatory variables, is a 
good way of obtaining the consistent estimator of unknown coefficients regarding respective population regression function. The instrumental variables regression is also broadly adopted way of estimation, when the potentially emerging causality bias between regressor and the outcome variables is observed, or - the omitted variable bias regarding the explanatory variable is claimed as unobserved and hence may not be included in the formal specification. To formalize the above, let us give: $y_{i}=\beta x_{i}+\varepsilon_{i}$, but $E\left(x_{i}, \varepsilon_{i}\right) \neq 0$, despite the exogeneity assumption requires $E\left(x_{i}, \varepsilon_{i}\right)=0$. Hence, to "omit" the endogeneity, we define $z_{i}$ as instrument which satisfies $E\left(z_{i}, \varepsilon_{i}\right) \neq 0$ and $E\left(z_{i}, \varepsilon_{i}\right)=0$. To obtain consistent $\beta$, we adopt 2SLS (two-step least squares) method where: $y_{i}=\beta x_{i}+\varepsilon_{i}$ and $x_{i}=\varphi z_{i}+\mu_{i}$,

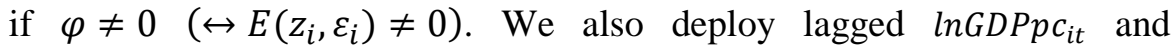
$\left(\operatorname{lnGDPp}_{i t}\right)^{2}\left(\left(\ln G D P p c_{i t}-1\right.\right.$-year lag), $\left(\operatorname{lnGDPp} c_{i t}\right)^{2}-1$-year lag $\left.)\right)$ as instruments, which are sufficiently correlated with $\operatorname{lnGDPp} c_{i t}$ and $\left(\operatorname{lnGDPp} c_{i t}\right)^{2}$ respectively, but uncorrelated with $\varepsilon_{i t}$, which allows producing unbiased $\delta_{1}$ and $\delta_{2}$. To get rid of the unobserved heterogeneity in models, first differences estimators (FDE) are often applied. However, we decide not to follow this approach. The first differencing of data implies that all estimates are generated for relative changes instead of levels, which brings risk of obtaining misleading results due to convergence process that characterizes analyzed countries. Convergence hypothesis support the logic that relatively poor economies experience higher rates of i.e. GDP per capita growth, if compared to rich ones. In our case, total fertility rate is expected to decrease along with economic growth, which results in positive correla-

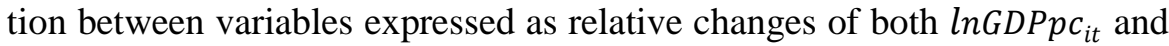
$T F R_{i t}$. If we assume the previous, concluding on the role of the economic growth in total fertility rate in-time variability might be confusing and leading to incorrect conclusions. Luci and Thévenon (2011) also refer to the problem and indicate that using FD estimator in this case might not allow for clear statement about the 'role of economic development for the fertility rebound in highly developed countries' (see: Luci and Thévenon, 2011).

To accomplish the second goal of the paper we calculate the vertex (turning point) of the parabola defined as in Eq.(2), which corresponds to averaged level of GDP per capita at which the fertility rebound takes place. If we assume that Eq.(2) is a 2-order polynomial, then its general form follows:

$$
f(x)=a x^{2}+b x+c,
$$

where $x \in(-\infty ;+\infty)$ and at least $a \neq 0$. 
Thus the vertex (turning point) of the Eq.(7) is defined as:

$$
\left(-\frac{b}{2 a}, f\left(-\frac{b}{2 a}\right)\right)
$$

Alternatively the (8) can be calculated by use of first derivative of (7):

$$
f^{\prime}(x)=2 a x+b
$$

and solving the equation:

$$
f^{\prime}(x)=2 a x+b=0 .
$$

The solution of Eq.(10), estimates level of GDP per capita corresponding to the threshold at which the relationship between TFR and GDPpc turns to be positive instead of negative.

\section{Results}

As it was explained, our empirical analysis is limited to countries where the fertility rebound was detected over the period 1970-2011. Finally have concentrated on 18 high-income economies, where total fertility rate fell below 2.1 - replacement rate, and after reaching the low point it was steadily increasing. Although growing trends in total fertility rates were to a point disrupted by short "ups" and "downs", the positive direction was maintained. Looking backwards, the reversal trends in TFR were preceded by long run and substantial falls in fertility rates. In 1970 the average total fertility rate was approximately $2.36^{5}$, then in $1980-1.77,1990-1.69$, $2000-1.60$ and finally in $2011-1.70$. Then the absolute change in average TFR between 1970 and 2000 was 0.76 . Basing on the previous, we conclude that the sharpest declines in total fertility rate were noted in decade 1970-1980, when the TFR fell below the threshold (2.1) required to replace country`s population. Countries that experienced most significant declines in TFR over the period 1970-1980 were Barbados (-1.1), Netherlands ($.98)$, Australia (-.96), Italy and Norway (-.78 for both). Reversely, we note that in 2011, the average TFR was slightly higher than in $2000(+0.1)$, thus over this decade the fertility rebound is revealed. Countries with greatest intensity of growing TFR over the period 2000-20111, were Sweden

\footnotetext{
${ }^{5}$ Own estimates for the 18 selected countries.
} 
(+.36), United Kingdom (+.34), Belgium and Greece (+.13 for both) and Italy (+.15). Observed, over last decade, positive changes in fertility rates probably are becoming a permanent feature rather than a mere cyclical change. However, the 41-year changes in total fertility rate do not resemble a smooth trend, but they are rather often interrupted by temporarily upward and downward trends. Furthermore, we confront total fertility rates versus economic growth. Our panel encompasses 18 countries covering long period, which constitutes a promise for accurate estimates. Adopted empirical procedures allow for controlling for both unobserved country and time specific effects. Relying on pooled OLS, we detect the best-fitting curve demonstrating changes of TFR it $_{\text {versus GDPpc }}$. Additionally we plot our panel to control for graphical specification of examined relationship. Figure 1 preliminarily confirms that analyzed countries follow the $U$ pattern over the period 1970-2011, if TFR $_{\text {it }}$ versus GDPpc $_{\text {it }}$ relationship is examined. Solid black line (Figure 1) approximates theoretical pattern between TFR $_{\text {it }}$ and $\mathrm{GDPpc}_{\mathrm{it}}$. For relatively low $\mathrm{GDPpc}_{\text {it }}$ the $\mathrm{TFR}_{\mathrm{it}}$ is high, but along with the process of economic growth it continuously declines, finally reaching the low point of the U-shaped curve (the parabola opens downward). Then, having passed the vertex, moderate increases in $\mathrm{TFR}_{\mathrm{it}}$ are revealed and the parabola opens upward. It supports the idea that the fertility rebound is accompanied by certain threshold level of GDPpc $\mathrm{it}_{\mathrm{it}}$.

Figure 1. Total Fertility Rate versus GDP per capita. 18 countries. Period 19702011

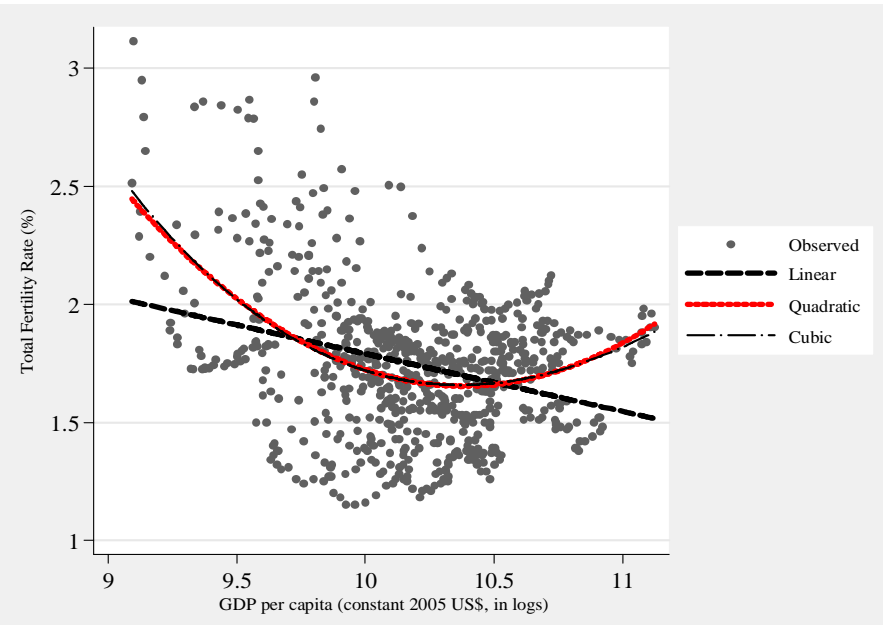

Source: own elaboration based on data derived from World Development Indicators 2013. 
Table 1 presents results of linear, quadratic and cubic predictions for $\mathrm{TFR}_{\text {it }}$ versus $\mathrm{GDPpc}_{\text {it. }}$ Quadratic model reveals the best fit to empirical data, as $\mathrm{R}^{2}=.196$ and all coefficients are statistically significant. Thus we conclude that the quadratic model, better than linear or cubic, predicts relationship between $\mathrm{TFR}_{\mathrm{it}}$ and $\mathrm{LnGDPpc}_{\mathrm{it}}$.

Table 1. Total Fertility Rate versus GDP per capita. Linear, quadratic and cubic predictions. 18 countries. Period 1970-2011

\begin{tabular}{|c|c|c|c|}
\hline & $\begin{array}{c}\text { Linear } \\
\text { prediction }\end{array}$ & $\begin{array}{l}\text { Quadratic } \\
\text { prediction }\end{array}$ & $\begin{array}{c}\text { Cubic } \\
\text { prediction }\end{array}$ \\
\hline & \multicolumn{3}{|c|}{ Pooled OLS } \\
\hline $\operatorname{LnGDPpc}_{i t}$ & $\begin{array}{c}-.25 \\
(-8.85)\end{array}$ & $\begin{array}{l}-10.09 \\
(-9.87)\end{array}$ & $\begin{array}{l}-18.33 \\
(-.66)\end{array}$ \\
\hline$\left(\operatorname{LnGDPpc}_{\mathrm{it}}\right)^{2}$ & & $\begin{array}{c}0.48 \\
(9.65)\end{array}$ & $\begin{array}{l}1.30 \\
(.47) \\
\end{array}$ \\
\hline$\left(\operatorname{LnGDPpc}_{\mathrm{it}}\right)^{3}$ & & & $\begin{array}{c}-.02 \\
(-.30) \\
\end{array}$ \\
\hline _cons & $\begin{array}{c}4.2 \\
(14.88)\end{array}$ & $\begin{array}{l}54.06 \\
(10.47)\end{array}$ & $\begin{array}{l}81.79 \\
(.87)\end{array}$ \\
\hline $\begin{array}{l}\mathrm{R}^{2} \text { of the model } \\
\text { adjusted }-\mathrm{R}^{2}\end{array}$ & $\begin{array}{l}.095 \\
.094\end{array}$ & $\begin{array}{l}.196 \\
.193 \\
\end{array}$ & $\begin{array}{l}.196 \\
.192 \\
\end{array}$ \\
\hline $\begin{array}{l}\text { \# of countries } \\
\text { \# of observations }\end{array}$ & $\begin{array}{c}18 \\
746\end{array}$ & $\begin{array}{c}18 \\
746\end{array}$ & $\begin{array}{c}18 \\
746\end{array}$ \\
\hline
\end{tabular}

Source: own estimates based on data derived from World Development Indicators 2013. Note: in parenthesis $t$-statistics at $5 \%$ significance level.

Table 2 summarizes full specification of estimation results based on multiple periods in 18 selected countries. The analysis is based on panel data; hence the evidence demonstrates the evolution of changing total fertility rates, which are attributed to economic growth. Displayed outcomes suggest that $T R F_{i t}$ and $G D P p c_{i t}$ are negatively correlated for lower per capita income (ante vertex of the curve), and the relationship turns to be positive for higher GDPpc $c_{i t}$, thus the U-shaped trajectory is generated. The estimates obtained from quadratic panel regressions of total fertility rates against economic growth; show that regressor $\left(\operatorname{lnGDPp} c_{i t}\right)$ always holds a negative sign, and $\left(\ln G D P p c_{i t}\right)^{2}-$ a positive one. In all cases, the estimated coefficients are statistically significant at 5\% level. In columns (1) and (2) the results of simple OLS are reported. The model with $\left(\ln G D P p \mathrm{c}_{\mathrm{it}}\right)$ - 2-year lag variable added, shows slightly higher R-square, which might suggest that the level of total fertility rate in period ( $t$ ) is to some extent preconditioned by GDP per capita in period (t-2). Estimates were also per- 
formed with $\left(\operatorname{lnGDPp} c_{i t}\right)$ - 1-year lag included, and they were significantly weaker that for the 2-year lag. This also supports the hypothesis that positive effects of economic growth on total fertility rates are revealed with significant time lags.

Table 2. Total Fertility Rate versus GDP per capita. Quadratic estimates. 18 countries. Period 1970-2011

\begin{tabular}{|c|c|c|c|c|c|c|c|c|}
\hline & \multicolumn{2}{|c|}{ Pooled OLS } & \multicolumn{2}{|c|}{ FE (I) } & \multicolumn{2}{|c|}{ FE (II) } & \multirow{2}{*}{$\begin{array}{c}\mathbf{F E} \\
\text { (III) } \\
(7) \\
\end{array}$} & \multirow{2}{*}{$\begin{array}{c}\text { FE } \\
(\text { IV) }\end{array}$} \\
\hline & (1) & (2) & (3) & (4) & (5) & (6) & & \\
\hline $\operatorname{LnGDPpc}_{\text {it }}$ & $\begin{array}{l}-10.09 \\
(1.01) \\
\end{array}$ & $\begin{array}{l}-9.19 \\
(.88) \\
\end{array}$ & $\begin{array}{l}-21.54 \\
(5.15) \\
\end{array}$ & $\begin{array}{l}-18.30 \\
(5.26)\end{array}$ & $\begin{array}{l}-14.56 \\
(5.79) \\
\end{array}$ & $\begin{array}{l}-14.61 \\
(5.88)\end{array}$ & $\begin{array}{l}-21.48 \\
(6.02)^{(\mathrm{a}}\end{array}$ & $\begin{array}{l}-14.65 \\
(7.09)^{(\mathrm{a}}\end{array}$ \\
\hline$\left(\operatorname{LnGDPpc}_{\mathrm{it}}\right)^{2}$ & $\begin{array}{l}0.48 \\
(.049)\end{array}$ & $\begin{array}{l}.422 \\
(.044)\end{array}$ & $\begin{array}{l}1.02 \\
(.25)\end{array}$ & $\begin{array}{l}.862 \\
(.26) \\
\end{array}$ & $\begin{array}{l}.724 \\
(.28) \\
\end{array}$ & $\begin{array}{l}.721 \\
(.28) \\
\end{array}$ & $\begin{array}{l}1.02 \\
(.29)^{(\mathrm{a})}\end{array}$ & $\begin{array}{l}.727 \\
(.35)^{(\mathrm{a})}\end{array}$ \\
\hline $\begin{array}{l}\text { LnGDPpc }_{\text {it }}- \\
\text { 2-year lag }\end{array}$ & & $\begin{array}{l}.434 \\
(.061)\end{array}$ & & $\begin{array}{l}.267 \\
(.09)\end{array}$ & & $\begin{array}{l}.064 \\
(.13)\end{array}$ & & \\
\hline _cons & $\begin{array}{l}54.06 \\
(5.1)\end{array}$ & $\begin{array}{l}46.99 \\
(4.6)\end{array}$ & $\begin{array}{l}114.22 \\
(26.1)\end{array}$ & $\begin{array}{l}95.78 \\
(27.3)\end{array}$ & $\begin{array}{l}75.46 \\
(29.9)\end{array}$ & $\begin{array}{l}75.49 \\
(30.6)\end{array}$ & $\begin{array}{l}113.87 \\
(30.55)^{(\mathrm{a}}\end{array}$ & $\begin{array}{l}75.9 \\
(35.9)^{(a)}\end{array}$ \\
\hline $\begin{array}{l}\mathrm{R}^{2} \text { of the } \\
\text { model }\end{array}$ & .196 & .259 & $\begin{array}{l}.466 \\
\text { (within) }\end{array}$ & $\begin{array}{l}.487 \\
\text { (within) }\end{array}$ & $\begin{array}{l}.590 \\
\text { (within) }\end{array}$ & $\begin{array}{l}.582 \\
\text { (within) }\end{array}$ & $\begin{array}{l}466 \\
\text { (within) } \\
\end{array}$ & $\begin{array}{l}.586 \\
\text { (within) }\end{array}$ \\
\hline $\begin{array}{l}\text { Year-fixed } \\
\text { Country-fixed } \\
\text { Instruments }\end{array}$ & $\begin{array}{l}\text { No } \\
\text { No } \\
\text { No }\end{array}$ & $\begin{array}{l}\text { No } \\
\text { No } \\
\text { No }\end{array}$ & $\begin{array}{l}\text { No } \\
\text { Yes } \\
\text { No }\end{array}$ & $\begin{array}{l}\text { No } \\
\text { Yes } \\
\text { No }\end{array}$ & $\begin{array}{l}\text { Yes } \\
\text { Yes } \\
\text { No }\end{array}$ & $\begin{array}{l}\text { Yes } \\
\text { Yes } \\
\text { No }\end{array}$ & $\begin{array}{l}\text { No } \\
\text { Yes } \\
\text { Yes }\end{array}$ & $\begin{array}{l}\text { Yes } \\
\text { Yes } \\
\text { Yes }\end{array}$ \\
\hline $\begin{array}{l}\# \text { of countries } \\
\# \text { of observa- } \\
\text { tion }\end{array}$ & $\begin{array}{l}18 \\
746\end{array}$ & $\begin{array}{l}18 \\
744\end{array}$ & $\begin{array}{l}18 \\
746\end{array}$ & $\begin{array}{l}18 \\
744\end{array}$ & $\begin{array}{l}18 \\
746\end{array}$ & $\begin{array}{l}18 \\
744\end{array}$ & $\begin{array}{l}18 \\
744\end{array}$ & $\begin{array}{l}18 \\
744\end{array}$ \\
\hline
\end{tabular}

Note: below coefficients - robust SE. All estimates for significance level at 5\%. ${ }^{\text {(a) }}$ - bootstrap SE (1000 replications). Lagged explanatory variable used as instruments. (I) - countryfixed effect. (II) - time-fixed effects. (III) - instrumented country-fixed effects regression. (IV) - instrumented time-fixed effects regression.

Source: own estimates based on data derived from World Development Indicators 2013.

Estimates of coefficients $\delta_{1}$ and $\delta_{2}$ resulted from within-estimator (FE(I)), explaining mediated effects of $\ln G D P p c_{i t}$ on TFR it due to crosscountry differences, are statistically significant however - in each case $-\delta_{1}$ tends to be higher than $\delta_{2}$. It suggests that, over the period 1970-2011, the "negative" relationship between $\mathrm{TFR}_{\mathrm{it}}$ and $\mathrm{GDPpc}_{\mathrm{it}}$ was strongly dominant. As in case of OLS estimates, inclusion of lagged GDPpc $\mathrm{it}_{\mathrm{it}}$, resulted on slightly higher $\mathrm{R}^{2}$ of the model (.487), which again confirms the lagged impact of economic growth on changes in total fertility rates. Analyzing relationship between total fertility rate and economic growth, we suppose that the impact of $\mathrm{GDPpc}_{\text {it }}$ on $\mathrm{TFR}_{\mathrm{it}}$ may be additionally determined by factors varying across time. Hence, to check for unexpected in-time variation, which potentially affects the influence of GDP per capita on $\left(T F R_{i t}\right)$, 
we control for time-fixed effects. The results obtained from FE(II) suggest that, after 'absorbing' the unobserved effects that vary across time and potentially determines the impact of GDPpc $c_{i t}$ on $\mathrm{TFR}_{\mathrm{it}}$, the strength and direction of the relationship remains at a level comparable to the estimates generated by FE(I). The R-square (within) of the model FE(II) is at 0.59 , thus we may conclude that the FE(II) regression - with time-fixed effects included -explains relatively better the relationship between total fertility rate and economic growth, than the FE(I) model. In FE(II) with lagged $\mathrm{GDPpc}_{\text {it }}$ included, the estimated coefficients also confirm the previous results and prove that the relationship between total fertility changes and economic growth in examined panel, is not specifically featured by country and/or time fixed effects, but rather is inter-temporal in its nature. However, to confirm the previous, we additionally run random-effects regression (results not reported in Table 2) and perform the Hausman test, which resulted in obtaining Prob $>\mathrm{chi}^{2}=.000$. It suggests that the relationship between total fertility rate and economic growthmight be, to some extent, additionally affected by omitted variables relatively constant over time, but varying across countries, and - some other variable relatively constant (fixed) for countries but varying over time. To control for potential endogeneity in models, in columns (7) and (8) we present results of instrumental variables estimator. All coefficients are reported under the assumption that lagged $\left(\operatorname{lnGDPp} c_{i t}\right)$ and $\left(\operatorname{lnGDPp} c_{i t}\right)^{2}$ are treated as instruments, and IV-regression was performed using 2SLS. The obtained outcomes are highly similar to those resulted from estimates with no instruments used, thus are not discussed in particular. The presence of time-invariant country specific effects, like i.e. culture, institutions etc., surely influence the relationship between $\mathrm{TFR}_{\text {it }}$ and economic growth, but their impact is not strong enough to eliminate an average response of $\mathrm{TFR}_{\mathrm{it}}$ if GDP per capita changes in analyzed countries over the period 1970-2011. Hence the 'panel effect' is not interrupted by occasional incidents. However, to some extent, our results seem to be, additionally conditioned by unobserved effects that tend to vary intime (not only across countries). The later justifies why variations in GDP per capita influence differently total fertility rate (determined by people`s behavior) at different points of time; and explains changes in patterns of total fertility rate over the period 1970-2011, as its significant falls are followed by moderate increases. Similar conclusions are presented in the works by Luci and Thévenon (2011), Myrskylä et al. (2009) and Furuoka (2009). As demonstrated in Figure 1, the relationship between total fertility rate and economic growth follows the U-shaped pattern, which is well described by quadratic models (confirmed by results presented in Table 2 above). The U-shaped patter approximated by quadratic function, yields 
existence of specific minimum (convex of the parabola), which depicts the threshold level of GDP per capita at which total fertility rate starts to rise and the downward trend is halted. Following previous estimates, the low peak of the curve (using OLS) corresponds to approximately lnGDPpc$\mathrm{it}=10.38$ which is equivalent to 32208 of GDP per capita (in 2005 constant US\$). Thus, when considering total fertility rate that changes as countries advance in terms of economic growth, rising fertility trends tend to be revealed once a country achieves the threshold level of GDP per capita 32208 (in 2005 constant US\$). The examined effects of economic growth on changing total fertility rates explain the averaged response of falling/rising $\mathrm{TFR}_{\mathrm{it}}$ as $\mathrm{GDPpc}_{\mathrm{it}}$ grows in hypothetical country. It shows that economic growth might be one of the channels inducing increases in total fertility rates. However, it shall be borne in mind that the study predominantly unveils the statistical relationships between TFR and GDP per capita.

The conclusions from the study are intentionally kept at a general level; hence they provide only a partial answer to the fertility rebound determinants. Keeping the rigid supposition that detected fertility rebound was exclusively driven by growth of national output, is based on weak foundations. The empirically based evidence shows that certain highly-developed countries reached the turning point in total fertility (once have decrease below replacement rate, the TFR increases), which hopefully designates structural shifts both in terms of economic and social conditions (Barlow, 1994; Brander \& Dorwick, 1994; Galor \& Zang, 1997; Dahan \& Tsiddon, 1998). However, a country`s specific effects and patterns explaining the behavior of total fertility rate versus economic growth may differ significantly (Thevenon, 2009; Goldstein, et al., 2013), as being affected wide array of factors. The root causes of emerging positive relationship between TFR and economic growth may be traced in technological progress and women`s better access to mass education (Becker, et al., 1994; Frejka, 2012; Ní Bhrolcháin \& Beaujouan, 2012), which allows for increasing the number of people engaged in formal market activities and multiplying returns from labour (Bacci, 2013). Structural reorientations, like i.e. shifts from agricultural to industrial economy, or emergence in service-based economy and labour force feminization (Schaller, 2012), are other recognized determinants of fertility declines. As number of women involved in labour force grows, they are less determined to bear children. The intensity of changes in social attitudes, religion, income inequalities (Repetto, 2013), or state policies designed toward fertility increases (Alesina \& Rodrick, 1994; Parr \& Guest, 2011), may potentially affect social norms or individual fertility choices (Barro \& Becker, 1989; Wang, et al., 1994; Hin, et al., 
2011; Orsal \& Goldstein, 2011; Neels, et al., 2013a; Neels, et al., 2013b). The latter may induce trends reversals in countries` fertility rates. Additionally, a question appears whether the observed growth in TFR is permanent or rather temporal. The uncertainty in the case is huge. Possibly the temporal increases in fertility rates are a direct consequence of demographic trends and the new 'fertility transition' might be the case. Or, alternatively, modest increases in TFR which are observed in different countries are the positive 'response' to pro-natal state policies, which are broadly incorporated in countries affected by low fertility. The latter, probably, is rather to be answered in a long-term horizon, as a 'combined response' of demographic and socio-economic changes (Galor \& Zang, 1997; Schultz, 2001; Bloom \& Finlay, 2009; Cervellati \& Sunde, 2011).

\section{Conclusions}

The paper was designed to uncover the relationship between changing total fertility rates and economic growth in 18 high-income economies over the period 1970-2011, and to depict the GDP-threshold at which the fertility rebound emerged. We have examined the relationship adopting longitudinal analysis, which allowed for obtaining averaged response of total fertility rates as countries advance in economic development pattern. Additionally, it was hypothesized that the U-shaped trajectory explains changes in longrun total fertility trends determined by economic growth, and the supposition was confirmed. Our estimates lead to the general conclusion that TFR $_{\text {it }}$ and $\mathrm{GDPpc}_{\mathrm{it}}$ are closely interrelated, and uncovered quantitative relationship that supports the hypothesis on inter-temporal nature of the links. Hence, the relationship between total fertility rate and economic growth is relatively robust to time and country specific effects. We have also discovered that the fertility rebound is especially to be revealed as countries achieve the threshold level of economic development approximated by GDP per capita 32208 (in 2005 constant US\$). Designating the turning point at U-shaped curve would imply that economic growth to a certain point constitutes a channel of reversing paths with regard to total fertility rates in high-income countries. The last one supports a more general idea that countries at higher stages of development tend to experience fertility rebound as per capita income is sufficient to provide a decent life and education for more children (Varvarigos, 2013). It may also suggest that some of developed countries are now entering a new phase of development, significantly marked by demographic change determined by reversals in fertility rates, which starts to recover and grow slightly above pure replacement 
rate. Although discovering such quantitative links between TFR and GDP per capita, we do not claim that achieving the threshold GDP per capita shall automatically induce increases in total fertility rates. Surely, not all countries will follow analogous paths of growing fertility, regardless they perform well or not in terms of economic growth. Additionally, the positive impact of growing income on fertility may finally be temporary and shortterm. Still, many developed countries do not experience the fertility rebound, which suggests that economic growth does not drive exclusively demographic changes, and fertility rebounds across countries are only partly explained by growth in living standards, while the rest of it is hugely attributed to institutional, social and state policy context.

\section{References}

Adsera, A., \& Menendez, A. (2009). Fertility changes in Latin America in the context of economic uncertainty (No. 4019). IZA discussion papers.

Alesina, A., \& Rodrik, D. (1994). Distributive politics and economic growth. The Quarterly Journal of Economics, 109(2), http://dx.doi.org/10.2307/2118470.

Bacci, M. L. (2012). A concise history of world population. John Wiley \& Sons.

Bacci, M. L. (2013). Low Fertility in Historical Perspective. Population and development review, 38(1).

Barlow, R. (1994). Population growth and economic growth: some more correlations. Population and Development Review, 20(1).

Barro, R. J., \& Becker, G. S. (1989). Fertility choice in a model of economic growth. Econometrica: journal of the Econometric Society, 57(2). http://dx.doi.org/10.2307/1912563.

Becker, G. S. (1960). An economic analysis of fertility. In: Demographic and economic change in developed countries. Columbia: Columbia University Press.

Becker, G. S., Murphy, K. M., \& Tamura, R. (1994). Human capital, fertility, and economic growth. In: Human Capital: A Theoretical and Empirical Analysis with Special Reference to Education. Chicago: The University of Chicago Press.

Becker, G. S., Glaeser, E. L., \& Murphy, K. M. (1999). Population and economic growth. American Economic Review, 89(2), http://dx.doi.org/10.1257/ aer.89.2.145.

Bengtsson, T., Campbell, C., \& Lee, J. Z. (2009). Life under pressure: Mortality and living standards in Europe and Asia, 1700-1900. Massachusetts: MIT Press Books.

Bloom, D. E., \& Finlay, J. E. (2009). Demographic change and economic growth in Asia. Asian Economic Policy Review, 4(1).

Bongaarts, J. (2002). The end of the fertility transition in the developed world. Population and development review, 28(3), http://dx.doi.org/10.1111/j.17284457.2002.00419.x. 
Bongaarts, J., \& Feeney, G. (1998). On the quantum and tempo of fertility. Population and development review, 24(2).

Bongaarts, J., \& Sobotka, T. (2012). A demographic explanation for the recent rise in European fertility. Population and Development Review, 38(1), http://dx.doi.org/10.1111/j.1728-4457.2012.00473.x.

Brander, J. A., \& Dowrick, S. (1994). The role of fertility and population in economic growth. Journal of Population Economics, 7(1).

Butler D. (2004). The fertility riddle. Nature 432, http://dx.doi.org/10.100 7/BF00160435.

Butz W.B., Ward M.P. (1979a). The emergence of country cyclical US fertility. The American Economic Review, 69(3).

Butz W.B., Ward M.P. (1979b). Will US fertility remain low? A new economic interpretation. Population Development Review, 5.

Caldwell, J. C., \& Schindlmayr, T. (2003). Explanations of the fertility crisis in modern societies: A search for commonalities. Population Studies, 57(3), http://dx.doi.org/10.1080/0032472032000137790.

Cervellati, M., \& Sunde, U. (2011). Life expectancy and economic growth: the role of the demographic transition. Journal of Economic Growth, 16(2), http://dx.doi.org/10.1007/s10887-011-9065-2.

Dahan, M., \& Tsiddon, D. (1998). Demographic transition, income distribution, and economic growth. Journal of Economic growth, 3(1).

Day, C. (2012). Economic Growth, Gender Wage Gap and Fertility Rebound. Economic Record, 88(1), http://dx.doi.org/10.1111/j.1475-4932.2012.00799.x.

Day, C. (2013). Skill Composition, Fertility, and Economic Growth. Review of Income and Wealth 2013, http://dx.doi.org/10.1111/roiw.12071.

Doepke, M. (2004). Accounting for fertility decline during the transition to growth. Journal of Economic growth, 9(3), http://dx.doi.org/10.1023/B:JOEG $.0000038935 .84627 . \mathrm{e} 4$.

Easterlin, R. A. (1975). An economic framework for fertility analysis. Studies in family planning, 6(3).

Frejka, T. (2010). Cohort overlays of evolving childbearing patterns: How postponement and recuperation are reflected in period fertility trends (No. WP2010-026). Max Planck Institute for Demographic Research, Rostock, Germany.

Frejka, T. (2012). The role of contemporary childbearing postponement and recuperation in shaping period fertility trends. Comparative Population Studies, 36(4).

Furuoka, F. (2009). Looking for a J-shaped development-fertility relationship: Do advances in development really reverse fertility declines. Economics bulletin, 29(4).

Galor O., Weil, D.N. (1996). The gender gap, fertility and growth. American Economic Review, 89.

Galor, O., \& Zang, H. (1997). Fertility, income distribution, and economic growth: theory and cross-country evidence. Japan and the world economy, 9(2). 
Galor, O., \& Weil, D. N. (1999). From Malthusian stagnation to modern growth, 2082.

Goldstein, J. R., Sobotka, T., \& Jasilioniene, A. (2009). The End of "Lowest-Low" Fertility?. Population and development review, 35(4), http://dx.doi.org/10.111 1/j.1728-4457.2009.00304.x.

Goldstein, J. R., Kreyenfeld, M., Jasilioniene, A., \& Örsal, D. K. (2013). Fertility reactions to the" Great Recession" in Europe: Recent evidence from orderspecific data. Demographic Research,29, http://dx.doi.org/10.4054/Dem Res.2013.29.4.

Gubhaju, B. B., \& Moriki-Durand, Y. (2003). Below-replacement fertility in East and Southeast Asia: consequences and policy responses. Journal of Population Research, 20(1).

Heer, D. M. (1966). Economic development and fertility. Demography, 3(2).

Hin, S., Gauthier, A., Goldstein, J., \& Bühler, C. (2011). Fertility preferences: what measuring second choices teaches us. Vienna Yearbook of Population Research.

Hirschman, C. (1994). Why fertility changes. Annual Review of Sociology, 20(1).

Kalemli-Ozcan, S., Ryder, H. E., \& Weil, D. N. (2000). Mortality decline, human capital investment, and economic growth. Journal of Development Economics, 62(1).

Kreyenfeld, M. (2010). Uncertainties in female employment careers and the postponement of parenthood in Germany. European Sociological Review, 26(3)

Klasen, S., \& Lamanna, F. (2009). The impact of gender inequality in education and employment on economic growth: new evidence for a panel of countries. Feminist Economics, 15(3).

Kohler, H. P., Billari, F. C., \& Ortega, J. A. (2002a). The emergence of lowest-low fertility in Europe during the 1990s. Population and Development Review, 28, http://dx.doi.org/10.1111/j.1728-4457.2002.00641.x.

Kohler, H.-P., Rodgers, J. L., \& Christensen, K. (2002b). Between nurture and nature: The shifting determinants of female fertility in Danish twin cohorts 1870-1968. Social Biology, 49.

Lee, R. (1990). The demographic response to economic crisis in historical and contemporary populations. Population Bulletin of the United Nations, 29.

Lee, R. (2003). The demographic transition: three centuries of fundamental change. Journal of Economic Perspectives, 17(4).

Luci, A., \& Thévenon, O. (2011). Does economic development explain the fertility rebound in OECD countries?. Population \& Sociétés, 481.

Luci-Greulich, A., \& Thévenon, O. (2013). The impact of family policies on fertility trends in developed countries. European Journal of Population/Revue européenne de Démographie, 29(4).

Macunovich, D. J. (1996). Relative income and price of time: Exploring their effects on US fertility and female labor force participation. Population and Development Review, 22.

Martin, J. (2004). The ultimate vote of confidence. Fertility rates and economic conditions in Australia, 1976-2000. Australian Social Policy, 2002-2003. 
Mills, M., \& Blossfeld, H.-P. (2005). Globalization, uncertainty and the early life course: A theoretical framework. In: H.-P. Blossfeld, E. Klijzing, M. Mills, \& K. Kurz (Eds.), Globalization, uncertainty and youth in society. London/New York: Routledge Advances in Sociology Series.

Mills, M., Rindfuss, R. R., McDonald, P., \& de Velde, E. (2011). Why do people postpone parenthood? Reasons and social policy incentives. Human Reproduction Update, 17(6).

Morgan, S. P., \& Taylor, M. G. (2006). Low fertility at the turn of the twenty-first century. Annual Review of Sociology, 32, http://dx.doi.org/10.1146/ann urev.soc.31.041304.122220.

Myrskylä, M., Kohler, H. P., \& Billari, F. C. (2009). Advances in development reverse fertility declines. Nature,460(7256), http://dx.doi.org/10.1038/nat ure08230.

Myrskylä, M., Kohler, H. P., \& Billari, F. (2011). High development and fertility: fertility at older reproductive ages and gender equality explain the positive link, PSC Working Papers.

Myrskylä, M., Goldstein, J. R., \& Cheng, Y. H. A. (2013). New cohort fertility forecasts for the developed world: rises, falls, and reversals. Population and Development Review, 39(1).

Neels, K. (2010a). Temporal variation in unemployment rates and their association with tempo and quantum of fertility: Some evidence for Belgium, France and the Netherlands. Paper presented at the Annual meeting of the Population Association of America, Dallas, 17 April OECD (2011), Doing better for families. OECD Publishing.

Neels, K., \& De Wachter, D. (2010b). Postponement and recuperation of Belgian fertility: how are they related to rising female educational attainment?. Wien: Vienna Yearbook of Population Research.

Neels, K., Theunynck, Z., \& Wood, J. (2013a). Economic recession and first births in Europe: recession-induced postponement and recuperation of fertility in 14 European countries between 1970 and 2005. International Journal of public health, 58(1).

Neels, K., \& de Wachter, D. (2013b). Postponement and recuperation of Belgian fertility. Ralentissements, résistances et ruptures dans les transitions démographiques: Actes de la Chaire Quetelet 2010.

Ní Bhrolcháin, M., \& Beaujouan, É. (2012). Fertility postponement is largely due to rising educational enrolment. Population studies, 66(3).

Ogawa, N. (2003). Japan's changing fertility mechanisms and its policy responses. Journal of Population Research, 20(1).

Orsal, D. D., \& Goldstein, J. R. (2010, April). The increasing importance of economic conditions on fertility. In: Annual meetings of the Population Association of America. Dallas, Texas, April.

Parr, N., \& Guest, R. (2011). The contribution of increases in family benefits to Australia's early 21 st-century fertility increase: An empirical analysis. Demographic Research, 25. 


\section{Piotr Dominiak, Ewa Lechman, Anna Okonowicz}

Prioux, F. (2007). Recent demographic developments in France: fertility at a more than 30-year high. Population-E, 62(03).

Varvarigos, D. (2013). A Theory of Demographic Transition and Fertility Rebound in the Process of Economic Development (No. 13/19).

Rindfuss, R. R., Morgan, S. P., \& Swicegood, G. (1988). First births in America: Changes in the timing of parenthood (Vol. 2). University of California Press.

Repetto, R. (2013). Economic equality and fertility in developing countries. Routledge.

Santow, G., \& Bracher, M. (2001). Deferment of the first birth and fluctuating fertility in Sweden. European Journal of Population, 17.

Schaller, J. (2012). Booms, busts, and fertility: Testing the Becker model using gender-specific labor demand. University of Arizona, unpublished manuscript.

Schultz, T. P. (2001). The fertility transition: Economic explanations. Economic Growth Center Discussion Paper, 833.

Sobotka, T., Billari, F. C., \& Kohler, H.-P. (2010). The return of late childbearing in developed countries: Causes, trends and implications. Vienna: Vienna Institute of Demography.

Sobotka, T., Skirbekk, V., \& Philipov, D. (2011). Economic recession and fertility in the developed world. Population and Development Review,37(2), http://dx.doi.org/10.1111/j.1728-4457.2011.00411.x.

Sobotka, T. (2012). Fertility in Austria, Germany and Switzerland: Is there a Common Pattern?. Comparative Population Studies, 36(2-3).

Thévenon, O. (2009). Does fertility respond to work and family reconciliation policies in France?. Fertility and public policy: How to reverse the trend of declining birth rates, INED Working Paper, 2009.

Wang, P., Yip, C. K., \& Scotese, C. A. (1994). Fertility choice and economic growth: Theory and evidence. The Review of Economics and Statistics, 76(2), http://dx.doi.org/10.2307/2109880.

Weil, D.N. (2013). Economic growth. Pearson.

Witte, J. C., \& Wagner, G. G. (1995). Declining fertility in East Germany after unification: A demographic response to socioeconomic change. Population and Development Review, 21(2).

Van de Kaa, D. J. (1987). Europe's second demographic transition. Population bulletin, 42(1). 